\title{
A re-examination of the timing of pupping for Steller sea lions Eumetopias jubatus breeding on two islands in Alaska
}

\author{
Carey E. Kuhn*, Kathryn Chumbley, Devin Johnson, Lowell Fritz \\ Marine Mammal Laboratory, Alaska Fisheries Science Center/National Marine Fisheries Service/NOAA, \\ 7600 Sand Point Way NE, Seattle, WA 98115, USA
}

\begin{abstract}
Steller sea lions are distributed from Japan to the California coast, USA, and population demographics vary spatially, with populations in some regions increasing while others are declining. To assess changes in population size, aerial surveys are conducted annually to quantify pup production. The timing of these surveys is critical for accurate population estimates, and survey windows were determined based on historical estimates of mean pupping date. We reassessed the timing of pupping for Steller sea lions at 2 breeding islands in the central Gulf of Alaska, USA (Marmot Island) and the eastern Aleutian Islands (Ugamak Island) for evidence of temporal shift. Using land-based counts of pups, we quantified mean pupping date and the duration of the pupping season between 2003 and 2013 and compared these data to historical mean pupping dates between 1977 and 1999. The mean pupping date of 9 June on Marmot Island was not significantly different than the mean pupping date on Ugamak Island, 8 June. On Marmot Island, mean pupping date differed by $3.7 \pm 0.9 \mathrm{~d}$ between beaches; however, mean pupping date did not differ between beaches on Ugamak Island. On Ugamak Island, mean pupping date was significantly earlier than previously reported by $2.5 \mathrm{~d}$, but this may be an artifact of the limited number of years available for comparison. On Marmot Island mean pupping date was not different from historical dates. On both islands, $94.2 \pm 1.6 \%$ of the pups were born prior to the planned start of aerial surveys in Alaska (23 June). Our results demonstrate that although mean pupping date was variable and may have shifted earlier relative to historical data at Ugamak Island, the current timing of the aerial survey is suitable for obtaining peak pup counts for Steller sea lions in these regions.
\end{abstract}

KEY WORDS: Marmot Island $\cdot$ Pupping date $\cdot$ Pup production $\cdot$ Reproduction $\cdot$ Ugamak Island

\section{INTRODUCTION}

Seasonality and synchrony in the timing of reproduction is a pattern found in numerous plant and animal species, which has been linked to increased reproductive success through a variety of mechanisms (Rutberg 1987, Ims 1990). Yet, many studies have found that both intrinsic and extrinsic factors can influence the timing of reproduction within a season. Intrinsic factors that play a role can include age, body size, and previous reproductive history (e.g. Lunn et

\footnotetext{
*Corresponding author: carey.kuhn@noaa.gov
}

al. 1994, Plard et al. 2014, Rotella et al. 2016). For example, Plard et al. (2014) showed that parturition date in roe deer was negatively related to adult quality (measured as median body mass) and age. Extrinsic factors such as resource availability and environmental factors may also play a role (e.g. Daan et al. 1988, Boyd 1996, Schaper et al. 2012). For South American sea lions Otaria flavescens, median birth dates were negatively correlated to prey availability and differed by up to $16 \mathrm{~d}$ over a 6 yr study period (Soto et al. 2004).

(C) Outside the USA the US Government 2017. Open Access under Creative Commons by Attribution Licence. Use, distribution and reproduction are unrestricted. Authors and original publication must be credited.

Publisher: Inter-Research · www.int-res.com 
Understanding the sources of variation in reproductive timing is critical because reproductive events, such as births, are often used as the baseline for other life-history studies (e.g. age-related survival, growth patterns) and for population assessments (Eberhardt et al. 1979, Bradshaw et al. 2000, Hastings et al. 2009). For example, for many species, counts of young are used to assess population size or track populations over time when direct counts of an entire population are unfeasible (Ling 1969, Eberhardt et al. 1979, Berkson \& DeMaster 1985). In pinnipeds (seals, sea lions, and walrus), newborn pups spend a period of time on land prior to entering the water, making them an ideal population segment to census (Berkson \& DeMaster 1985). If reproductive timing varies, then estimates of production can be falsely reduced or inflated, impacting measures of population size, which are vital for demographic studies and for development of successful management and conservation strategies.

Because their breeding locations are remote, distant from each other, and span a large geographic region, population counts of Steller sea lions Eumetopias jubatus in US waters are primarily conducted via aerial surveys and supplemented with some landor boat-based counts (Westlake et al. 1997, Snyder \& Pitcher 2001, Fritz et al. 2016). Accurate indices of population size are critical for this species because population trends vary substantially across the species' range (Johnson \& Fritz 2014). Steller sea lions are widely distributed throughout the Pacific Rim from Japan to California, USA (Kenyon \& Rice 1961, Loughlin et al. 1984, NMFS 2008). The population is separated into 2 distinct population segments (DPS), eastern and western, based on genetic and demographic differences between regions, which are divided at $144^{\circ} \mathrm{W}$ longitude (Bickham et al. 1996, Loughlin 1997).

In 1990, after large declines in Steller sea lion numbers, the species was listed as threatened range-wide under the US Endangered Species Act (ESA). Following continued population declines in the western DPS, in 1997 the listing was changed to endangered for the western DPS (National Oceanic and Atmospheric Administration 1997). The eastern DPS has increased at a rate of approximately $3 \% \mathrm{yr}^{-1}$ since the 1970s (Pitcher et al. 2007, Fritz et al. 2016) and was removed from the list of ESA-threatened species in 2013 (NMFS 2013). The decline in the western DPS in Alaska likely ended in 2003 and between 2003 and 2015, counts of both pups and non-pups (1 yr and older) have increased in most areas (Johnson \& Fritz 2014, Fritz et al. 2016). Nonetheless, within the western DPS, sea lion numbers remain well below historic levels and regional variability in demographic trends remain significant (Johnson \& Fritz 2014).

For Steller sea lion pup production estimates, aerial surveys in Alaska are generally conducted during a 3 wk period between late June and mid-July when most pups are $\leq 1$ mo old (Pitcher et al. 2001, Fritz et al. 2016). The aerial survey window was determined based on historical measures of mean pupping date (Pitcher et al. 2001) with the goal of conducting counts near the peak of pupping (defined as the date of maximum pup counts) but before most pups begin entering the water (Gentry 1970, Sandegren 1970, Pitcher et al. 2001). The current timing of Steller sea lion aerial surveys in Alaska (preferred window of 23 June to 10 July) assumes that the timing of pupping has not changed since 1999 when it was last examined for Steller sea lions breeding in the USA (Pitcher et al. 2001).

The objective of this study was to reassess mean pupping date and determine if there is evidence for variability in the timing of pupping for Steller sea lions. We quantified mean pupping date at 2 breeding islands in the central Gulf of Alaska (Marmot Island) and the eastern Aleutian Islands (Ugamak Island) over $10 \mathrm{yr}$ between 2003 and 2013. In addition, we assessed whether the current timing of aerial surveys occurs near the date of peak pupping, which is essential for accurate estimates of pup production.

\section{MATERIALS AND METHODS}

\section{Data collection}

Data were collected between 2003 and 2013 by land-based observers at Marmot Island (Kodiak archipelago, Alaska, USA; 58 $13.6^{\prime} \mathrm{N}, 151^{\circ} 47.8^{\prime} \mathrm{W}$ ) and Ugamak Island (western side of Unimak Pass, Alaska; $54^{\circ} 13.5^{\prime} \mathrm{N}, 164^{\circ} 47.5^{\prime} \mathrm{W}$; Fig. $1 \mathrm{~A}$, Table A1 in the Appendix). In 2006, the field season was suspended for the month of June on Marmot Island and canceled on Ugamak Island because of a research injunction, which resulted in insufficient data to model mean pupping date in that year. Between May/June and August each year, counts were conducted daily, weather permitting, at Beaches 4 (MB4) and 7 (MB7) on Marmot Island (Fig. 1B) and at 'Beach South' (UBS) on Ugamak Island (Fig. 1C). A second beach on Ugamak Island, 'Beach North' (UBN, Fig. 1C), was observed intermittently with a goal of at least one visitation per week. A detailed 

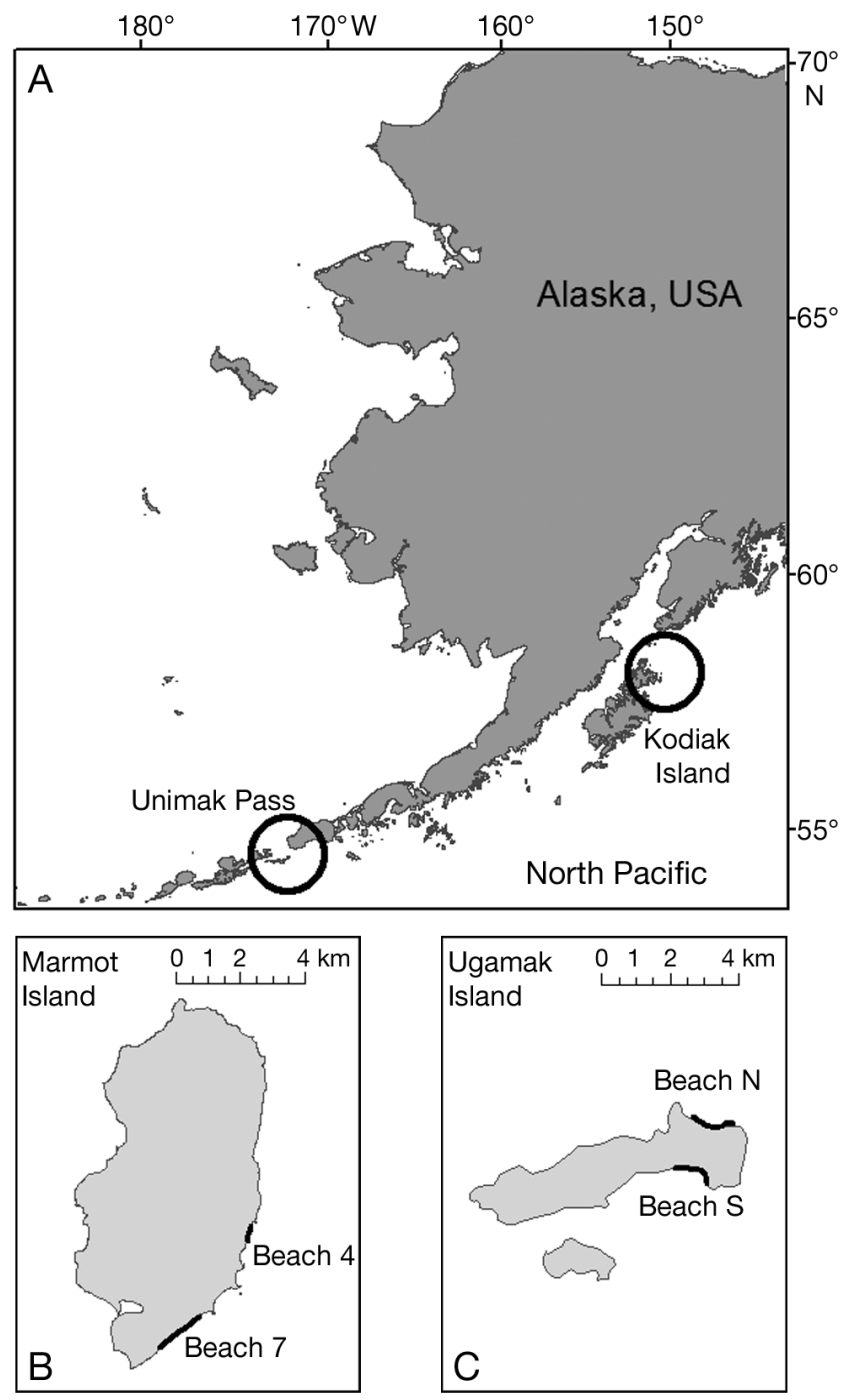

Fig. 1. (A) Steller sea lion research sites (circles) on Marmot and Ugamak islands (Alaska, USA). Marmot Island is located $45 \mathrm{~km}$ northeast of Kodiak Island in the Central Gulf of Alaska; Ugamak Island is on the western side of Unimak Pass in the Eastern Aleutian Islands. $(B, C)$ Black lines show breeding beaches on each island: (B) Beach 4 (MB4) and Beach 7 (MB7) on Marmot Island; (C) Beach North (UBN) and Beach South (UBS) on Ugamak Island

description of the data collection procedures can be found in Chumbley et al. (1997) and Wilson et al. (2012).

From cliff edges approximately 200 to $300 \mathrm{~m}$ above the rookeries, at least one count of sea lions by age-sex classes was conducted per day between 10:00 and 18:00 h (local time) using binoculars or spotting scopes. Pups were also counted hourly during a weekly dawn-to-dusk survey. Each count was assigned a confidence category based on the observers' assessment of completeness: 'complete' (ob- server was confident all sea lions present were counted); 'partial' (all visible sea lions were counted but some sea lions may not have been visible from the observation site); and 'complete partial' (a special category for UBN where the entire beach area cannot be observed from the counting location, indicating that every pup in the viewable region was counted). For partial counts, observer comments were used to identify and remove counts that were incomplete (e.g. 'large proportion of pups in the surf not counted' and 'fog moved in; low confidence in total') in order to ensure anomalously low counts did not influence the model parameters. 'Estimate' counts and any other counts where observer comments signified potentially poor data were not included in data analysis. When both count types occurred within a year at a beach, they were generally distributed throughout the survey period (e.g. in 2012, as shown in Fig. 2 below). Because of pup movements into and out of visible areas (or the water), partial counts were equal to or higher than complete counts within the same day on multiple occasions. In these cases, the highest total count was used for that day.

\section{Pup count growth model and statistical analysis}

A logistic growth model (Trites 1992, Pitcher et al. 2001) was fit to daily pup counts for each of the 4 beaches separately (MB4, MB7, UBN and UBS; Fig. 2). When modeling counts at each beach, annual variation in logistic parameters was accommodated with a random effect for each year. For beach $i$ in year $j$, observed cumulative pup production on day $d$ was modeled as follows:

$$
N_{d}=\frac{\phi_{1 i j}}{1+\exp \left\{-\frac{d-\phi_{2 i j}}{\phi_{3 i j}}\right\}}+\epsilon_{i j d}
$$

where $N_{d}$ is the total number of pups observed on day $d_{1} \phi_{1 i j}$ is the pup production asymptote, $\phi_{2 i j}$ is the mean date of birth, $\phi_{3 i j}$ is a scale parameter controlling birth synchrony, and $\epsilon_{i j d}$ is an error term with $N\left(0, \sigma_{i}^{2}\right)$ distribution. For the $\phi_{1}$ and $\phi_{3}$ parameters we used the following parameterization for $k=1,3$; log $\phi_{k i j}=\beta_{k i}+\alpha_{k i j}$, where $\beta_{k i}$ is the parameter intercept and $\alpha_{k i j}$ is a $N\left(0, \tau_{k i}^{2}\right)$ random effect. The $\phi_{2}$ parameters were modeled in the same fashion without the $\log$ transformation. To account for leap years, date was based on days since 1 May (i.e. 1 May $=0$ and 2 May $=1$ ). All calendar dates presented are calculated from a common year. 


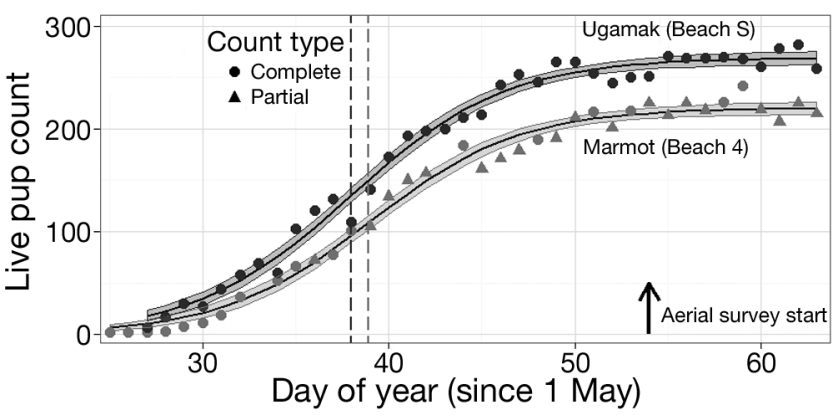

Fig. 2. Example of the results of the logistic growth model for Steller sea lion pup production, based on counts in 2012, at Beach 4, Marmot Island (light gray) and Beach S, Ugamak Island (dark gray) (Alaska, USA). Shaded areas encompass the $95 \%$ CIs; points along the curve are live pup counts. Counts are separated between 'complete' and 'partial' counts' to show the variability in count types between locations (Table A1). Vertical dashed lines denote mean pupping dates: 8 June at Beach 4 (light gray); 7 June at Beach S (dark gray). The planned start of the aerial survey, June 23 (Day 53), is marked with an arrow

Only pup counts prior to 4 July (MB4, MB7, and UBS) were used for analysis due to potential dispersal of females with pups and reduced sightability of pups as they mature and begin swimming (RaumSuryan et al. 2004, Marine Mammal Laboratory unpubl. data). A longer survey period was required at MB4 in 2004 (until 8 July) due to a late season sampling gap and at UBN in all years (until 9 July) due to the reduced sampling effort and greater time gaps between samples. Mean pupping date (MPD) was defined as the date when pup count estimates reached one-half of the maximum pup count in the model (i.e. the asymptote). As in previous analyses for Steller sea lions (Pitcher et al. 2001), no adjustments were made for pup mortality, which resulted in MPD estimates being negatively biased (Trites 1992). For example, for northern fur seals Callorhinus ursinus, MPD was biased between 0.1 and $2.0 \mathrm{~d}$ earlier when pup mortality was not taken into account (Trites 1992, Kunisch 2011). To determine if the timing of pupping has changed since 1999, estimates of MPD were compared to those from Pitcher et al. (2001) for Marmot and Ugamak islands. The date by which $90 \%$ of the pups were born was a derived parameter from the model which was determined by calculating $90 \%$ of the asymptote pup count and identifying the date this value was reached. Similarly, the proportion of pups born prior to the start of the planned aerial survey (23 June) was a derived model parameter determined by calculating the number of pups born on 22 June and dividing that value by the maximum pup count from the model.
Statistical analysis was conducted using R ( R Core Team 2015). Parameters and random effects were estimated using Markov chain Monte Carlo (MCMC) via the 'rstan' package (Stan Development Team 2015). The MCMC was run for 30000 iterations following a burn-in of 10000 iterations which were discarded. The posterior mean and $95 \%$ credible intervals (CIs) were calculated for all parameters and derived parameters (e.g. island averages or differences between island parameters). Island MPD was calculated by averaging MPD for beaches at each island. No weighting factor was used because maximum pup count values were similar between beaches within an island.

To compare current MPD with historical data from Pitcher et al. (2001), we assumed a normal posterior distribution around the published MPD values and sampled 20000 values in order to make comparisons between current and historical posterior distributions. The resulting yearly historical values were averaged for each island and compared to the current posterior distribution for MPD by island. Historical MPD at each island was considered significantly different from current MPD if the resulting $95 \%$ CIs of the posterior differences did not include zero. Summary data for MPD, date of $90 \%$ pupping, and proportion of pups born by the planned start of the aerial survey are reported as means \pm posterior standard deviations (SD).

\section{RESULTS}

\section{Data collection}

The earliest start date for pup count surveys was 24 May in 2013 and the latest end date was 1 August in 2007 and 2011 (Table A1). The total number of daily pup counts used in the model and the proportion of complete counts varied among years, islands, and beaches (Table A1). At MB7, a late start in 2005 (first count on Day 41) and too few counts in 2003 and 2004 resulted in a poor model fit. At UBN, insufficient sampling, late starts, or large time gaps (up to $8 \mathrm{~d}$ ) resulted in poor model fits for 2003, 2004, 2007, 2008, and 2013. As a result, these years were removed from the analysis.

\section{Mean pupping date}

MPD was not significantly different between Marmot (9 June) and Ugamak (8 June) islands when all 
years were averaged (Table 1 ; difference $1.3 \mathrm{~d}, \mathrm{CI}$ -0.3 to $3.1 \mathrm{~d}$ ). Differences among yearly estimates of MPD ranged between -0.4 and 2.6 d later at Marmot Island, with MPDs at Marmot Island significantly later than those at Ugamak Island in only 3 years
(2009, 2010 and 2011). When beaches were examined separately, MPD was $3.7 \pm 0.9 \mathrm{~d}$ later at MB7 than MB4 (Table 1; CI -5.5 to $-2.1 \mathrm{~d}$ ), but there were no differences between beaches on Ugamak Island. On Marmot Island, annual estimates of MPD were

Table 1. Model estimates for timing of pupping of Steller sea lions on 4 beaches in Alaska (MB4 and MB7 on Marmot Island, and UBS and UBN on Ugamak Island; see Fig. 1) between 2003 and 2013: mean pupping date (MPD), date of $90 \%$ pup production, the proportion of pups born by the planned start of the aerial survey on 23 June (Day 53), and maximum pup production estimated from the model (asymptotes). Estimates are shown as mean \pm posterior SD. Dates are shown as number of days since 1 May in each year, with corresponding calendar dates determined based on a common year. Beach and island averages were calculated for all years pooled. * Significant difference between beaches within a year or, for pooled data, between beach averages on an island

\begin{tabular}{|c|c|c|c|c|c|c|c|}
\hline Location & Year & MPD & $\begin{array}{l}\text { MPD } \\
(\mathrm{d} \mathrm{mo})\end{array}$ & $\begin{array}{l}90 \% \text { pupping } \\
\text { date }\end{array}$ & $\begin{array}{l}90 \% \text { pupping } \\
\text { (d mo) }\end{array}$ & $\begin{array}{l}\text { Proportion born } \\
\text { prior to survey }\end{array}$ & $\begin{array}{l}\text { Asymptote } \\
\text { estimate }\end{array}$ \\
\hline MB4 & 2003 & $37.7 \pm 0.4$ & 7 June & $49.6 \pm 1.0$ & 19 June & $0.944 \pm 0.01$ & $177.2 \pm 2.8$ \\
\hline MB4 & 2004 & $38.2 \pm 0.5$ & 8 June & $49.3 \pm 1.1$ & 19 June & $0.949 \pm 0.01$ & $216.1 \pm 5.7$ \\
\hline MB4 & 2005 & $38.1 \pm 0.4$ & 8 June & $48.0 \pm 0.8$ & 18 June & $0.965 \pm 0.01$ & $151.0 \pm 2.5$ \\
\hline MB4 & 2007 & $38.7 \pm 0.2^{*}$ & 8 June & $48.1 \pm 0.5$ & 18 June & $0.966 \pm 0.01$ & $185.1 \pm 1.7$ \\
\hline MB4 & 2008 & $37.3 \pm 0.3^{*}$ & 7 June & $47.4 \pm 0.8^{*}$ & 17 June & $0.968 \pm 0.01^{*}$ & $202.9 \pm 3.2$ \\
\hline MB4 & 2009 & $38.5 \pm 0.2^{*}$ & 8 June & $49.4 \pm 0.5^{*}$ & 19 June & $0.949 \pm 0.01^{*}$ & $235.5 \pm 2.0$ \\
\hline MB4 & 2010 & $37.9 \pm 0.4^{*}$ & 7 June & $48.4 \pm 0.9^{*}$ & 18 June & $0.958 \pm 0.01^{*}$ & $250.6 \pm 5.1$ \\
\hline MB4 & 2011 & $38.0 \pm 0.3^{*}$ & 8 June & $48.1 \pm 0.7^{*}$ & 18 June & $0.962 \pm 0.01^{*}$ & $258.0 \pm 3.5$ \\
\hline MB4 & 2012 & $38.9 \pm 0.3$ & 8 June & $48.0 \pm 0.7$ & 18 June & $0.967 \pm 0.01$ & $220.5 \pm 3.2$ \\
\hline MB4 & 2013 & $37.2 \pm 0.2^{*}$ & 7 June & $46.6 \pm 0.4^{*}$ & 16 June & $0.975 \pm 0.003$ & $281.8 \pm 2.4$ \\
\hline MB7 & 2003 & $41.8 \pm 2.2$ & 11 June & $52.8 \pm 4.9$ & 22 June & $0.900 \pm 0.07$ & $244.4 \pm 20.0$ \\
\hline MB7 & 2004 & $41.9 \pm 2.3$ & 11 June & $52.9 \pm 4.8$ & 22 June & $0.897 \pm 0.07$ & $245.0 \pm 20.5$ \\
\hline MB7 & 2005 & $41.8 \pm 2.3$ & 11 June & $52.8 \pm 4.6$ & 22 June & $0.900 \pm 0.07$ & $245.1 \pm 20.8$ \\
\hline MB7 & 2007 & $42.2 \pm 0.4^{*}$ & 12 June & $50.3 \pm 1.1$ & 20 June & $0.948 \pm 0.02$ & $242.2 \pm 5.8$ \\
\hline MB7 & 2008 & $42.2 \pm 0.4^{*}$ & 12 June & $51.7 \pm 0.9^{*}$ & 21 June & $0.924 \pm 0.02^{*}$ & $239.0 \pm 5.2$ \\
\hline MB7 & 2009 & $42.6 \pm 0.5^{*}$ & 12 June & $54.4 \pm 1.5^{*}$ & 24 June & $0.873 \pm 0.03^{*}$ & $237.1 \pm 6.4$ \\
\hline MB7 & 2010 & $43.0 \pm 0.7^{*}$ & 13 June & $55.1 \pm 1.5^{*}$ & 25 June & $0.860 \pm 0.03^{*}$ & $247.0 \pm 8.5$ \\
\hline MB7 & 2011 & $42.9 \pm 0.9^{*}$ & 12 June & $57.6 \pm 2.0^{*}$ & 27 June & $0.820 \pm 0.04^{*}$ & $227.2 \pm 9.4$ \\
\hline MB7 & 2012 & $39.3 \pm 0.3$ & 9 June & $49.5 \pm 0.7$ & 19 June & $0.951 \pm 0.01$ & $263.0 \pm 3.8$ \\
\hline MB7 & 2013 & $40.2 \pm 0.3^{*}$ & 10 June & $48.7 \pm 0.7^{*}$ & 18 June & $0.964 \pm 0.01$ & $255.3 \pm 4.3$ \\
\hline MB4 & Average & $38.0 \pm 0.3^{*}$ & 8 June & $48.2 \pm 0.5^{*}$ & 18 June & $0.962 \pm 0.01$ & $217.9 \pm 3.2$ \\
\hline MB7 & Average & $41.8 \pm 0.8^{*}$ & 11 June & $52.3 \pm 1.6^{*}$ & 22 June & $0.912 \pm 0.03$ & $244.5 \pm 10.5$ \\
\hline UBN & 2003 & $38.8 \pm 3.9$ & 8 June & $52.0 \pm 13.2$ & 22 June & $0.907 \pm 0.09$ & $301.3 \pm 68.7$ \\
\hline UBN & 2004 & $39.0 \pm 4.0$ & 9 June & $52.0 \pm 7.7$ & 22 June & $0.905 \pm 0.09$ & $301.4 \pm 66.4$ \\
\hline UBN & 2005 & $37.4 \pm 0.8$ & 7 June & $50.8 \pm 2.2$ & 20 June & $0.928 \pm 0.03$ & $300.0 \pm 8.6$ \\
\hline UBN & 2007 & $39.0 \pm 4.8$ & 9 June & $52.1 \pm 8.5$ & 22 June & $0.905 \pm 0.09$ & $301.2 \pm 55.8$ \\
\hline UBN & 2008 & $39.0 \pm 3.9$ & 9 June & $52.3 \pm 10.6$ & 22 June & $0.904 \pm 0.10$ & $302.4 \pm 79.3$ \\
\hline UBN & 2009 & $37.5 \pm 1.0$ & 7 June & $48.1 \pm 2.7$ & 18 June & $0.958 \pm 0.03$ & $284.1 \pm 10.9$ \\
\hline UBN & 2010 & $39.5 \pm 1.0$ & 9 June & $51.1 \pm 3.1$ & 21 June & $0.925 \pm 0.04$ & $269.8 \pm 11.9$ \\
\hline UBN & 2011 & $39.0 \pm 0.6$ & 9 June & $51.6 \pm 1.7$ & 21 June & $0.919 \pm 0.02^{*}$ & $298.7 \pm 7.9$ \\
\hline UBN & 2012 & $40.1 \pm 1.2^{*}$ & 10 June & $54.8 \pm 2.5^{*}$ & 24 June & $0.870 \pm 0.04^{*}$ & $332.0 \pm 16.2$ \\
\hline UBN & 2013 & $38.8 \pm 3.8$ & 8 June & $52.4 \pm 16.1$ & 22 June & $0.906 \pm 0.08$ & $302.3 \pm 61.4$ \\
\hline UBS & 2003 & $37.4 \pm 0.5$ & 7 June & $46.6 \pm 0.9$ & 16 June & $0.976 \pm 0.01$ & $299.6 \pm 6.7$ \\
\hline UBS & 2004 & $38.1 \pm 0.3$ & 8 June & $48.5 \pm 0.8$ & 18 June & $0.958 \pm 0.01$ & $244.7 \pm 3.4$ \\
\hline UBS & 2005 & $38.9 \pm 0.4$ & 8 June & $47.9 \pm 0.9$ & 17 June & $0.968 \pm 0.01$ & $263.0 \pm 6.5$ \\
\hline UBS & 2007 & $38.8 \pm 0.3$ & 8 June & $47.9 \pm 0.6$ & 17 June & $0.970 \pm 0.01$ & $302.2 \pm 3.8$ \\
\hline UBS & 2008 & $38.1 \pm 0.4$ & 8 June & $47.1 \pm 0.8$ & 17 June & $0.973 \pm 0.01$ & $312.1 \pm 5.9$ \\
\hline UBS & 2009 & $38.5 \pm 0.4$ & 8 June & $47.1 \pm 0.8$ & 17 June & $0.976 \pm 0.01$ & $306.0 \pm 6.1$ \\
\hline UBS & 2010 & $38.5 \pm 0.3$ & 8 June & $48.0 \pm 0.8$ & 18 June & $0.966 \pm 0.01$ & $293.8 \pm 4.7$ \\
\hline UBS & 2011 & $39.0 \pm 0.3$ & 9 June & $47.8 \pm 0.6$ & 17 June & $0.970 \pm 0.01^{*}$ & $321.9 \pm 4.9$ \\
\hline UBS & 2012 & $38.0 \pm 0.2^{*}$ & 8 June & $47.2 \pm 0.5^{*}$ & 17 June & $0.972 \pm 0.01^{*}$ & $270.0 \pm 3.2$ \\
\hline UBS & 2013 & $37.7 \pm 0.3$ & 7 June & $46.6 \pm 0.6$ & 16 June & $0.977 \pm 0.01$ & $266.7 \pm 3.7$ \\
\hline UBN & Average & $38.8 \pm 1.4$ & 8 June & $51.2 \pm 2.9$ & 21 June & $0.923 \pm 0.04$ & $299.3 \pm 38.7$ \\
\hline UBS & Average & $38.3 \pm 0.3$ & 8 June & $47.5 \pm 0.5$ & 17 June & $0.971 \pm 0.004$ & $288.0 \pm 4.9$ \\
\hline $\begin{array}{l}\text { Marmot } \\
\text { Island }\end{array}$ & Average & $39.9 \pm 0.4$ & 9 June & $50.3 \pm 0.9$ & 20 June & $0.936 \pm 0.01$ & - \\
\hline $\begin{array}{l}\text { Ugamak } \\
\text { Island }\end{array}$ & Average & $38.6 \pm 0.7$ & 8 June & $49.3 \pm 1.5$ & 19 June & $0.947 \pm 0.02$ & - \\
\hline
\end{tabular}


significantly later at MB7 than MB4 in 6 years with the largest differences occurring in 2010 (5.1 $\pm 0.8 \mathrm{~d}$ later; Table 1). On Ugamak Island, the only annual difference in MPD between beaches occurred in 2012 when female sea lions pupped significantly later at UBN (3.0 d, CI 0.7 to $5.3 \mathrm{~d}$; Table 1). When beaches were averaged, MPD on Marmot Island was not different from the historical data (1979 to 1998: 9 June) (Pitcher et al. 2001). However, on Ugamak Island, MPD was $2.5 \mathrm{~d}$ earlier than historical data (1977 to1999: 11 June; CI -4.1 to -0.8 d) (Pitcher et al. 2001).

\section{Pupping season and aerial survey schedule}

In all years, $90 \%$ of the pups were born by Day 49.8 \pm 1.2 (19 June). This date was not significantly different between islands (Table 1; difference $0.9 \mathrm{~d}$, CI -2.3 to $4.1 \mathrm{~d}$ ) or between beaches on Ugamak Island (Table 1; difference $3.8 \mathrm{~d}, \mathrm{CI}-1.6$ to $9.2 \mathrm{~d}$ ). The date of $90 \%$ pupping was significantly later at MB7 than at MB4 (Table 1; difference $-4.1 \mathrm{~d}, \mathrm{CI}-7.4$ to $-0.8 \mathrm{~d}$ ), which is a reflection of the differences in MPD at these beaches. On Ugamak Island, annual estimates of the $90 \%$ pupping date differed only in 2012, the year when MPD at UBN was also later (Table 1).

Prior to the planned start of the aerial survey (23 June), the proportion of pups born at both islands was $0.942 \pm 0.02$, and this did not vary between island (Table 1 ; difference -0.01 , CI -0.06 to 0.04 ). When beaches were considered separately, the proportion of pups born prior to the survey did not differ (Marmot difference $0.05, \mathrm{CI}-0.003$ to 0.10 ; Ugamak difference -0.05 , CI: -0.12 to 0.02 ). For both islands, the proportion of pups born prior to the start of the survey ranged from $0.89 \pm 0.02$ (Marmot 2010) to 0.97 \pm 0.005 (Marmot 2013) among years.

\section{DISCUSSION}

By conducting extensive observational research over a 10 yr period, data collected during this study were used to examine the timing of reproduction in a pinniped species that breeds in remote, hard-toaccess locations. The land-based counts of pups born at Marmot and Ugamak islands should be considered an index of pup production at these locations and not a census of total pup production (Merrick et al. 1988, Chumbley et al. 1997, Kirkwood et al. 2005). Factors that impact the visibility (e.g. fog, rain, heat haze) and the ability to sight pups (e.g. observation height, topography) vary significantly at each beach (Merrick et al. 1988, Chumbley et al. 1997), which likely explains the differing ratios of complete to partial counts (Table A1). Nevertheless, for this study it was not necessary to get complete counts of the pups born at each beach, only consistent counts of pups within the sampled regions to detect changes in pup numbers over the reproductive period.

Overall, we found that MPD did not differ between islands during the study period; however, there was some interannual variability. During 3 consecutive years of this study (2009 to 2011), sea lions at Marmot Island showed a pattern of slightly later pupping by $1.4 \pm 0.7 \mathrm{~d}$ to $2.6 \pm 0.6 \mathrm{~d}$ (95\% CI: 1.4 to $3.8,0.09$ to 2.8 and 0.2 to 2.5 in 2009, 2010 and 2011 respectively). Breeding synchrony is the general pattern for many pinnipeds, though for species with wide-spread distributions, geographic or latitudinal variation has been found in the timing of reproduction (Boyd 1991, Wickens \& York 1997). Marmot and Ugamak islands are near the center of the Steller sea lions large geographic range and are separated by less than $1000 \mathrm{~km}$ (Fig. 1), making geographic or latitudinal variation in MPD unlikely. Historically, a difference in MPD was not found between Marmot and Ugamak islands (Pitcher et al. 2001). The cause of the interannual variation between islands in this study is unknown; however, for many pinniped species, including Antarctic fur seals Arctocephalus gazella and South American sea lions, a strong relationship has been found between annual pupping date and prey availability (Boyd 1996, Soto et al. 2004).

In contrast to the inter-island comparisons for MPD, when all years were combined there was a significant difference between beaches for MPD on Marmot Island. This difference was greater than $3 \mathrm{~d}$, yet no difference was found between beaches on Ugamak Island. A similar pattern of later pupping by sea lions at MB7 was also described by Chumbley et al. (1997), but statistical comparisons were not made. At such a small geographic scale $(<5 \mathrm{~km})$, it is unlikely that the later pupping date on MB7 could result from dissimilarities in prey availability. However, other factors that may influence pupping beach selection could play a role in the variation in pupping dates. For some pinniped species, older or prime-aged females give birth earlier in the season than younger females (Lunn \& Boyd 1993, Gentry 1998, Boltnev \& York 2001, Maniscalco et al. 2006, Hastings \& Jemison 2015). This was reported for Steller sea lions that breed on Chiswell Island, Alaska, and the Forrester Island Complex, Alaska (Maniscalco et al. 2006, Hastings \& Jemison 2015). For Antarctic fur seals it 
was suggested that, by returning earlier, older females could select the most suitable pupping sites (Lunn \& Boyd 1993). If beach MB4 on Marmot Island is the most suitable site for pupping, it could potentially be occupied first by prime-aged females, leaving MB7 for young sea lions that pup at a later date.

Movements of mother-pup pairs between beaches could also impact our calculation of MPD leading to differences between beaches at Marmot Island. Steller sea lion pups can enter the water as early as $2 \mathrm{wk}$ of age and disperse from a breeding beach with their mothers at 2 mo of age (Sandegren 1970, Merrick et al. 1988, Raum-Suryan et al. 2004). On Marmot Island, observations of permanently marked sea lions suggest that as the reproductive season progresses some sea lions move from MB4 to MB7 (Chumbley et al. 1997, Marine Mammal Laboratory unpubl. data). In addition, Chumbley et al. (1997) described movement of mother-pup pairs away from MB4 starting in mid-July and, in 1991, a late season survey (July 31) found that MB4 was almost completely abandoned, whereas MB7 counts remained unchanged (Chumbley et al. 1997). If female sea lions from MB4 or other beaches moved their pup to MB7 during the count period, this would result in an increase in daily pup counts unrelated to births at that beach, which would push the estimated MPD later. Similar small-scale movements by mother-pup sea lions pairs during the breeding season have been described for Steller sea lions at the Forrester Island Complex, Alaska (Hastings \& Jemison 2015).

Based on comparisons with historical data (1977 to 1999), it appears that there has been no change for MPD at Marmot Island but a potential shift to earlier pupping at Ugamak Island, i.e. $3 \mathrm{~d}$ earlier than recorded by Pitcher et al. (2001). Unfortunately, only 3 yr of data were available for comparison from Ugamak Island (Pitcher et al. 2001). Given the interannual variability in MPD at Ugamak Island, which ranged over 1.5 d between 2003 and 2013, it is difficult to discern if there has been an actual shift in mean pupping over time or if our results are an artifact of the small historical sample size ( $3 \mathrm{yr}$ ) used for comparison. If a change in pupping date has occurred, with sea lions on Ugamak Island pupping earlier, it is important to consider whether this small shift is biologically important. The pupping season for Steller sea lions generally occurs over a 2 mo period (mid-May through mid-July) (Calkins \& Pitcher 1982, Merrick et al. 1988) and Merrick et al. (1988) estimated that at least $90 \%$ of pups are born by the last week of June. This pattern is reflected in our data as pups were counted on the earliest obser- vation date (24 May 2013), and in all cases the date by which $90 \%$ of the pups were born occurred prior to the end of June (i.e. Day 60, Table 1). Therefore, although variability may exist in MPD between beaches, occasionally between islands, and even between our study and historical MPDs, there does not appear to be a significant shift in the overall pupping season for Steller sea lions at these 2 islands.

The existing variability we found in MPD, both temporal and spatial, could have an influence on estimates of population trends determined via aerial surveys (Calkins \& Pitcher 1982, Fritz et al. 2008, 2013). However, when all beaches were combined, $94 \%$ of pups were born prior to the survey start (23 June) and this did not differ between islands or beaches within an island. Based on the beach maximum count estimates (asymptote values, Table 1), this results in the potential for on average only 13 to 18 pups to be born at each beach after the survey starts. In addition, the survey takes several weeks to complete, which would result in an even higher proportion of pups born as the survey progresses (Fritz et al. 2008, 2016). Because the aerial surveys are scheduled to balance the trade-off between waiting for pups to be born and the increase in time pups spend in the water as they age, our results suggest that aerial surveys are still suitably timed to ensure the majority of pups are born when surveys are conducted.

\section{CONCLUSIONS AND CONSERVATION IMPLICATIONS}

Monitoring changes in the timing of reproduction is critical for population assessment and management of Steller sea lion stocks. We found that MPD is consistent between the 2 study islands, with some interannual variability. In addition, there may have been a slight shift to an earlier MPD from historical data at Ugamak Island but this is based on only 3 historical years for comparison. As a result, the current timing of the aerial survey is suitable to monitor changes in Steller sea lion pup production in these regions. It may be necessary to examine the timing of Steller sea lion births in other parts of Alaska (e.g. Central and Western Aleutian islands) to ensure that aerial surveys are properly timed in these regions. However, given that Pitcher et al. (2001) also reported a MPD of 9 June on Medny Island (Commander Islands, Russia), we do not expect the timing of births in the rest of the Aleutian Islands between Ugamak and Medny islands to be significantly different. 
The counts of Steller sea lions obtained during aerial surveys are considered a vital part of the continuing research guided by the Steller sea lion recovery plan (NMFS 2008). In addition, the recovery plan calls for focused research on sea lion population growth and reproduction to assess the relative impacts of threats to Steller sea lion population recovery (NMFS 2008). By identifying population level, multi-year patterns in MPD, researchers can now start to examine factors related to interannual and individual variation in this vital rate, such as impacts of environmental change, prey availability, maternal age, and reproductive history (e.g. Lunn et al. 1994, Bowen et al. 2003, Soto et al. 2004). An understanding of these relationships may help reduce the 'substantial uncertainty' that affects the ability to understand population-level threats responsible for the lack of recovery and, in some cases, continued regional declines within this population (NMFS 2008).

Acknowledgements. This research was conducted under Marine Mammal Protection Act permits \#782-1532, 7821768, 782-1889, and 14326. Many thanks to the 65 dedicated and hardy individual field camp observers, some over multiple field seasons, who conducted counts often in less than hospitable conditions. We thank aerial survey crews (NOAA Twin Otter crews), Morgan Lynn and Jim Gilpatrick (SWFSC), Katie Sweeney, Erin Kunisch, and Josh Cutler (AFSC), Katie Luxa and Josh Cutler (AFSC) for editing data and database management and Maritime Helicopters (Kodiak, AK) for field camp transportation. The findings and conclusions in the paper are those of the authors and do not necessarily represent the views of the National Marine Fisheries Service.

\section{LITERATURE CITED}

Berkson JM, DeMaster DP (1985) Use of pup counts in indexing population changes in pinnipeds. Can J Fish Aquat Sci 42:873-879

Bickham JW, Patton JC, Loughlin TR (1996) High variability for control-region sequences in a marine mammal: implications for conservation and biogeography of Steller sea lions (Eumetopias jubatus). J Mammal 77:95-108

Boltnev AI, York AE (2001) Maternal investment in northern fur seals (Callorhinus ursinus): interrelationships among mothers' age, size, parturition date, offspring size and sex ratios. J Zool (Lond) 254:219-228

Bowen WD, Ellis SL, Iverson SJ, Boness DJ (2003) Maternal and newborn life-history traits during periods of contrasting population trends: implications for explaining the decline of harbour seals (Phoca vitulina), on Sable Island. J Zool (Lond) 261:155-163

Boyd IL (1991) Environmental and physiological factors controlling the reproductive cycles of pinnipeds. Can J Zool 69:1135-1148

Boyd IL (1996) Individual variation in the duration of pregnancy and birth date in Antarctic fur seals: the role of environment, age, and sex of fetus. J Mammal 77: 124-133
Bradshaw CJA, Davis LS, Lalas C, Harcourt RG (2000) Geographic and temporal variation in the condition of pups of the New Zealand fur seal (Arctocephalus forsteri): evidence for density dependence and differences in the marine environment. J Zool (Lond) 252:41-51

Calkins DG, Pitcher KW (1982) Population assessment, ecology, and trophic relationships of Steller sea lions in the Gulf of Alaska. Alaska Department of Fish and Game, Anchorage, AK

Chumbley K, Sease J, Strick M, Towell R (1997) Field studies of Steller sea lions (Eumetopias jubatus) at Marmot Island, Alaska, 1979 through 1994. NOAA Tech Memo NMFS-AFSC-77, US Dept of Commerce, Springfield, VA

Daan S, Dijkstra C, Drent R, Meijer T (1988) Food supply and the annual timing of avian reproduction. In: Proc Int Ornithol Cong 19: 392-407

Eberhardt LL, Chapman DG, Gilbert JR (1979) A review of marine mammal census methods. Wildl Monogr 63:3-46

Fritz L, Lynn M, Kunisch E, Sweeney K (2008) Aerial, ship and land-based surveys of Steller sea lions (Eumetopias jubatus) in Alaska, June and July 2005-2007. NOAA Tech Memo NMFS-AFSC-183, US Dept of Commerce, Springfield, VA

Fritz L, Sweeney K, Johnson D, Lynn M, Gelatt T, Gilpatrick J (2013) Aerial and ship-based surveys of Steller sea lions (Eumetopias jubatus) conducted in Alaska in June-July 2008 through 2012, and an update on the status and trend of the western distinct population segment in Alaska. NOAA Tech Memo NMFS-AFSC-251, US Dept of Commerce, Springfield, VA

Fritz L, Sweeney K, Towell R, Gelatt T (2016) Aerial and ship-based surveys of Steller sea lions (Eumetopias jubatus) conducted in Alaska in June-July 2013 through 2015, and an update on the status and trend of the western distinct population segment in Alaska. NOAA Tech Memo NMFS-AFSC-321, US Dept of Commerce, Springfield, VA

Gentry RL (1970) Social behavior of the Steller sea lion. PhD dissertation, University of California, Santa Cruz, CA

Gentry RL (1998) Behavior and ecology of the northern fur seal. Princeton University Press, Princeton, NJ

Hastings KK, Jemison LA (2015) Age-specific variation in timing of parturition in Steller sea lions at Forrester Island Complex, Alaska. Mar Mamm Sci 32:777-785

*Hastings KK, Gelatt TS, King JC (2009) Postbranding survival of Steller sea lion pups at Lowrie Island in Southeast Alaska. J Wildl Manag 73:1040-1051

Ims RA (1990) The ecology and evolution of reproductive synchrony. Trends Ecol Evol 5:135-140

Johnson DJ, Fritz L (2014) agTrend: a Bayesian approach for estimating trends of aggregated abundance. Methods Ecol Evol 5:1110-1115

Kenyon KW, Rice DW (1961) Abundance and distribution of the Steller sea lion. J Mammal 42:223-234

Kirkwood R, Gales R, Terauds A, Arnould JPY and others (2005) Pup production and population trends of the Australian fur seal (Arctocephalus pusillus doriferus). Mar Mamm Sci 21:260-282

Kunisch E (2011) Northern fur seal reproductive rates and early maternal care. MS dissertation, Oregon State University, Corvallis, OR

Ling JK (1969) A review of ecological factors affecting the annual cycle in island populations of seals. Pac Sci 23: 399-413 
Loughlin TR (1997) Using the phlogeographic method to identify Steller sea lion stocks. In: Dizon AE, Chivers SJ, Perrin WF (eds) Molecular genetics of marine mammals. Special Publication 3, Society for Marine Mammalogy, Anacortes, WA, p 159-171

Loughlin TR, Rugh DJ, Fiscus CH (1984) Northern sea lion distribution and abundance: 1956-1980. J Wildl Manag 48:729-740

Lunn NJ, Boyd IL (1993) Effects of maternal age and condition on parturition and the perinatal period of Antarctic fur seals. J Zool (Lond) 229:55-67

Lunn NJ, Boyd IL, Croxall JP (1994) Reproductive-performance of female Antarctic fur seals: the influence of age, breeding experience, environmental variation and individual quality. J Anim Ecol 63:827-840

Maniscalco JM, Parker P, Atkinson S (2006) Interseasonal and interannual measures of maternal care among individual Steller sea lions (Eumetopias jubatus). J Mammal 87:304-311

Merrick R, Gearin P, Osmek S, Withrow D (1988) Field studies of northern sea lions at Ugamak Island, Alaska during the 1985 and 1986 breeding seasons. NOAA Tech Memo NMFS-F/NWC-143, US Dept of Commerce, Springfield, VA

National Oceanic and Atmospheric Administration (1997) Threatened fish and wildlife: change in listing status of Steller sea lions under the Endangered Species Act. Fed Regist 62:24345-24355

NMFS (2008) Recovery plan for the Steller sea lion: eastern and western distinct population segments (Eumetopias jubatus). Revision. National Marine Fisheries Service, Silver Spring, MD

NMFS (2013) Status review of the eastern distinct population segment of Steller sea lion (Eumetopias jubatus). National Marine Fisheries Service, Alaska Region, Juneau, AK

*Pitcher KW, Burkanov VN, Calkins DG, Le Boeuf BJ, Mamaev EG, Merrick RL, Pendleton GW (2001) Spatial and temporal variation in the timing of births of Steller sea lions. J Mammal 82:1047-1053

Pitcher KW, Olesiuk PF, Brown RF, Lowry MS and others (2007) Abundance and distribution of the eastern North Pacific Steller sea lion (Eumetopias jubatus) population. Fish Bull (Wash DC) 107:102-115

Plard F, Gaillard JM, Coulson T, Hewison AJM and others (2014) Long-lived and heavier females give birth earlier in roe deer. Ecography 37:241-249

R Core Team (2015) R: a language and environment for statistical computing. R Foundation for Statistical Computing, Vienna

Raum-Suryan KL, Rehberg MJ, Pendleton GW, Pitcher KW, Gelatt TS (2004) Development of dispersal, movement patterns, and haul-out use by pup and juvenile Steller sea lions (Eumetopias jubatus) in Alaska. Mar Mamm Sci 20:823-850

* Rotella JJ, Paterson JT, Garrott RA (2016) Birth dates vary with fixed and dynamic maternal features, offspring sex, and extreme climatic events in a high-latitude marine mammal. Ecol Evol 6:1930-1941

Kutberg AT (1987) Adaptive hypotheses of birth synchrony in ruminants: an interspecific test. Am Nat 130: 692-710

Sandegren FE (1970) Breeding and maternal behavior of the Steller sea lion (Eumetopias jubatus) in Alaska. MS dissertation, University of Alaska, Fairbanks, AK

Schaper SV, Dawson A, Sharp PJ, Gienapp P, Caro SP, Visser ME (2012) Increasing temperature, not mean temperature, is a cue for avian timing of reproduction. Am Nat 179:E55-E69

Snyder GM, Pitcher KW (2001) Counting Steller sea lion pups in Alaska: an evaluation of medium-format, color aerial photography. Mar Mamm Sci 17:136-146

Soto KH, Trites AW, Arias-Schreiber M (2004) The effects of prey availability on pup mortality and the timing of birth of South American sea lions (Otaria flavescens) in Peru. J Zool (Lond) 264:419-428

Stan Development Team (2015) Stan: a C++ library for probability and sampling, Version 2.8.0. http://mc-stan.org/ (accessed 23 Dec 2015)

* Trites AW (1992) Reproductive synchrony and the estimation of mean date of birth from daily counts of northern fur seal pups. Mar Mamm Sci 8:44-56

Westlake RL, Perryman WL, Ono KA (1997) Comparison of vertical aerial photographic and ground censuses of Steller sea lions at Año Nuevo Island, July 1990-1993. Mar Mamm Sci 13:207-218

Wickens P, York AE (1997) Comparative population dynamics of fur seals. Mar Mamm Sci 13:241-292

Wilson K, Fritz L, Kunisch E, Chumbley K, Johnson D (2012) Effects of research disturbance on the behavior and abundance of Steller sea lions (Eumetopias jubatus) at two rookeries in Alaska. Mar Mamm Sci 28:E58-E74 


\section{APPENDIX}

Table A1. Field season length and pup count effort on Marmot and Ugamak islands (Alaska, USA) between 2003 and 2013. Pup count days are the total number of days per season that at least 1 pup count was conducted. Different beaches divided by slashes, i.e. Marmot Island: Beach 4 [MB4]/Beach 7 [MB7]; Ugamak Island: Beach N [UBN]/Beach S [UBS]. Counts used for model are the filtered daily counts and only include counts prior to 4 July (Day 64) for all beaches, except UBN in all years (9 July, Day 69) and MB4 in 2004 (8 July, Day 68). The proportion of complete counts indicates the ratio of counts listed as complete counts or complete partial counts (at UBN) in relation to partial counts. NA: beaches with insufficient data to model or poor model fits due to time gaps or late starts

\begin{tabular}{|lcccccc|}
\hline Island & Year & $\begin{array}{c}\text { Start } \\
\text { date } \\
\text { (mm.dd) }\end{array}$ & $\begin{array}{c}\text { End } \\
\text { date } \\
\text { (mm.dd) }\end{array}$ & $\begin{array}{c}\text { Pup } \\
\text { count } \\
\text { days }\end{array}$ & $\begin{array}{c}\text { Counts } \\
\text { used for } \\
\text { model }\end{array}$ & $\begin{array}{c}\text { Proportion } \\
\text { complete } \\
\text { counts }\end{array}$ \\
\hline Marmot & 2003 & 05.29 & 07.31 & $53 / 18$ & $35 / \mathrm{NA}$ & $0.77 / \mathrm{NA}$ \\
& 2004 & 05.28 & 07.28 & $51 / 9$ & $31 / \mathrm{NA}$ & $0.74 / \mathrm{NA}$ \\
& 2005 & 06.06 & 07.27 & $49 / 34$ & $26 / \mathrm{NA}$ & $0.65 / \mathrm{NA}$ \\
& 2007 & 05.27 & 08.01 & $55 / 45$ & $32 / 25$ & $0.78 / 0.36$ \\
& 2008 & 05.29 & 07.27 & $46 / 41$ & $27 / 27$ & $0.15 / 1.0$ \\
& 2009 & 05.28 & 07.26 & $51 / 37$ & $33 / 24$ & $0.52 / 0.54$ \\
& 2010 & 05.28 & 07.28 & $58 / 39$ & $36 / 25$ & $0.31 / 0.28$ \\
& 2011 & 05.26 & 07.25 & $52 / 48$ & $31 / 26$ & $0.26 / 0.73$ \\
& 2012 & 05.25 & 07.25 & $57 / 42$ & $37 / 29$ & $0.49 / 0.52$ \\
& 2013 & 05.24 & 07.24 & $52 / 39$ & $35 / 22$ & $0.51 / 0.41$ \\
& 2003 & 06.04 & 07.26 & $11 / 41$ & NA/21 & NA/1.0 \\
& 2004 & 05.29 & 07.29 & $23 / 56$ & NA/30 & NA/1.0 \\
& 2005 & 06.02 & 07.29 & $20 / 55$ & $12 / 25$ & $0 / 0.96$ \\
& 2007 & 05.29 & 07.27 & $9 / 57$ & NA/35 & NA/0.86 \\
& 2008 & 06.02 & 07.31 & $9 / 57$ & NA/31 & NA/0.10 \\
2009 & 06.04 & 07.30 & $19 / 49$ & $11 / 24$ & $0.09 / 0.58$ \\
& 010 & 06.01 & 07.31 & $30 / 62$ & $19 / 31$ & $0 / 0.03$ \\
2011 & 06.02 & 08.01 & $32 / 56$ & $21 / 30$ & $0.95 / 0.10$ \\
2012 & 05.28 & 07.31 & $43 / 65$ & $30 / 37$ & $1.0 / 1.0$ \\
2013 & 05.28 & 07.31 & $23 / 64$ & NA/35 & NA/1.0 \\
\hline
\end{tabular}

Editorial responsibility: Sascha Hooker, St. Andrews, UK
Submitted: January 25, 2016; Accepted: November 23, 2016 Proofs received from author(s): February 9, 2017 